\title{
Ecological and Evolutionary Significance of Nutritional Flexibility in Planktotrophic Larvae of the Deep Sea Red Crab Geryon quinquedens and the Stone Crab Menippe mercenaria*
}

\author{
S. D. Sulkin and W. F. van Heukelem \\ Horn Point Environmental Laboratories, Center for Environmental and Estuarine Studies, University of Maryland, Cambridge, \\ Maryland 21613, USA
}

\begin{abstract}
Larvae of crab species inhabiting the shallow water marine environment show a wide range in nutritional requirements that must be satisfied via the diet. The present study compares the dietary requirements of larvae of the deep sea red crab Geryon quinquedens Smith with those of the stone crab Menippe mercenaria Say, a shallow water species. Stone crab larvae cannot survive to metamorphosis on a rotifer diet. Red crab larvae show no difference in survival to metamorphosis on rotifer and brine shrimp nauplius diets, although some delay in development is seen on the former diet. We speculate that increased nutritional flexibility exhibited by the red crab is related to its deep water habitat and that evolution of such flexibility may be required for penetration of that habitat.
\end{abstract}

\section{INTRODUCTION}

It seems reasonable that flexibility in qualitative dietary needs will be adaptive for species with planktotrophic larvae. Thus adaptations which reduce dependence on the capture of specific prey needed to satisfy nutritional requirements are likely to be favored by natural selection. Yet species such as the blue crab Callinectes sapidus Rathbun (Sulkin, 1975) and the spider crab Libinia emarginata (Bigford, 1978) show specific nutritional needs which must be satisfied via the diet. On the other hand larvae of the mud crabs Rhithropanopeus harrisii (Gould) and Neopanope texana sayi can survive to metamorphosis on prey species which are unable to sustain C. sapidus and L. emarginata (Sulkin and Norman, 1976). Thus crab species show considerable variability in nutritional flexibility during larval development.

Species tested to date hatch and in most cases complete larval development in highly productive, shallow estuarine or coastal marine waters. The present study was undertaken to compare the nutritional needs of a

\footnotetext{
- Contribution No, 1068 of the Center for Environmental and Estuarine Studies, University of Maryland, USA.
}

deeper water crab species with those of species occupying more shallow water.

The red crab Geryon quinquedens Smith inhabits the continental slope off the eastern coast of North America. Its larvae hatch at depths exceeding $200 \mathrm{~m}$ (Wigley et al., 1975; Haefner, 1978). The dietary requirements of red crab larvae are compared to those of the stone crab Menippe mercenaria Say, a marine species which accupies shallow water habitats. The concept of nutritional flexibility as it relates to habitat is discussed in light of these results and those of earlier studies.

\section{MATERIALS AND METHODS}

Comparative studies using nauplii of the brine shrimp Artemia salina (L.) and the rotifer Brachionus plicatilis Muller have been useful in establishing the presence of critical dietary requirements during larval development and in comparing these requirements among species (Sulkin, 1975; Sulkin and Norman, 1976; Bigford, 1978; Anger and Nair, 1979). In these experiments, failure of the larvae to develop to metamorphosis on the rotifer diet has been regarded as evidence of nutritional vulnerability. In the present 
experiments, larvae of Menippe mercenaria and Geryon quinquedens were raised from hatching on these two diets.

Ovigerous Menippe mercenaria were obtained commercially from Florida and ovigerous Geryon quinquedens from Rhode Island. Crabs were flown to our laboratories and kept in conditions suitable to each species. Eggs were removed from the pleopods, placed in appropriate medium, and agitated on a reciprocating shaker (110 rpm). The culture medium consisted of filtered natural seawater set at $30 \mathrm{ppt}$ salinity, $25^{\circ} \mathrm{C}$ for M. mercenaria; and at $35 \mathrm{ppt}$ salinity, $20^{\circ} \mathrm{C}$ for $G$. quinquedens. In the latter case, the salinity of natural sea water was increased by the addition of synthetic sea salts. The light/dark cycle was set at 12:12 l:d for both species.

Upon hatching, available larvae were placed, in groups of ten, into small culture dishes containing 50 $\mathrm{ml}$ of medium. For the offspring of any one crab, groups (siblings) were assigned randomly to one of the two test diets.

Culture dishes were examined daily for evidence of dead larvae and exuviae. Living larvae were transferred to fresh medium and fed, in excess. The techniques for maintaning the diets have been described in detail elsewhere (Sulkin and Epifanio, 1975).

For Menippe mercenaria, a total of 110 larvae were assigned to the brine shrimp diet; 100 , to the rotifer diet. The larvae came from three females. For Geryon quinquedens, 140 larvae from four females were tested on each diet.

Survivorship of larvae on a daily and instar basis and the mean day (and range) of each molt are calculated for each species. Methods of statistical analysis are described with the results.

\section{RESULTS}

\section{Menippe mercenaria}

The graph in Figure 1 shows daily survivorship for larvae raised on rotifers and brine shrimp nauplii. Survival to the megalopa on the brine shrimp diet was $31.8 \%$, whereas no larvae fed rotifers developed to the megalopa (Table 1). Indeed survival past the third zoeal stage was rare.

Table 2 shows a comparison of mean days of molt for larvae fed both diets (see also Fig. 1). Development to the first molt was significantly faster on the rotifer diet, although the situation is reversed by the third molt.

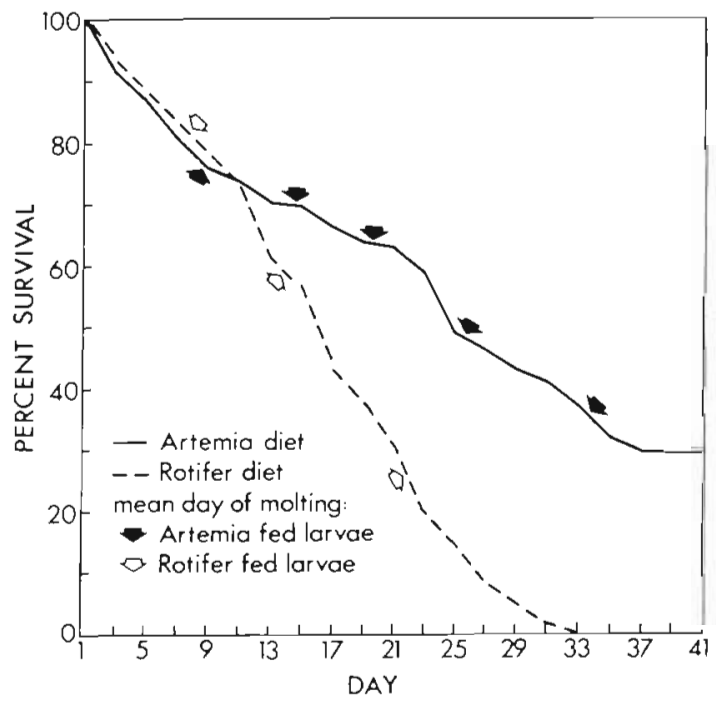

Fig. 1. Menippe mercenaria. Daily survivorship for larvae raised on either the rotifer Brachionus plicatilis or the nauplius of the brine shrimp Artemia salina

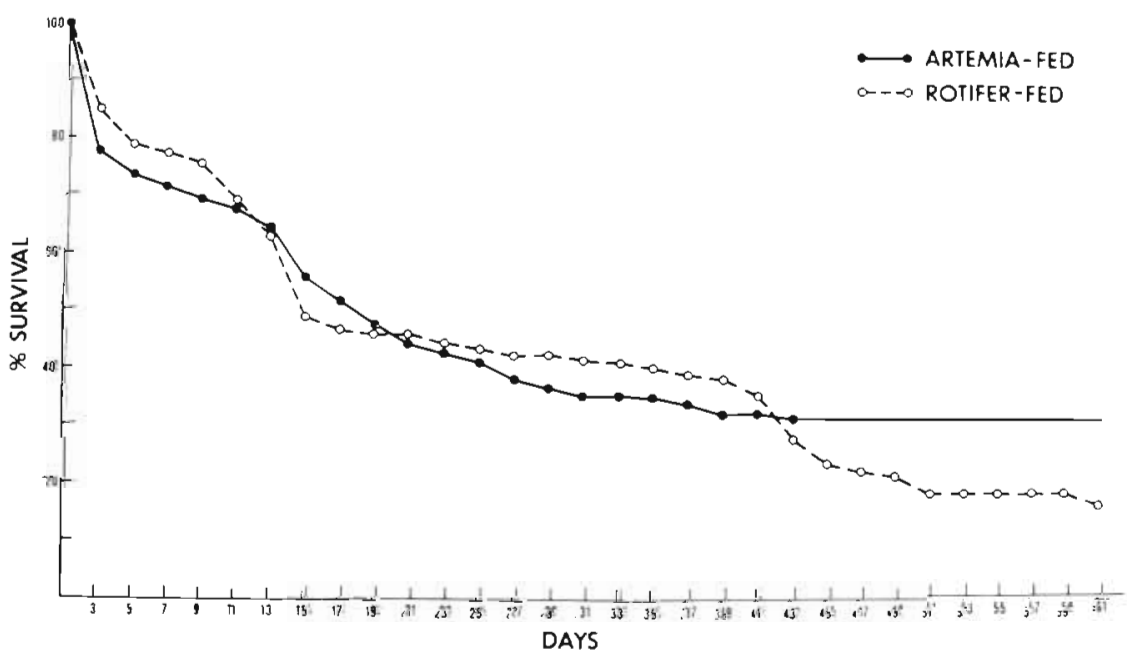

Fig. 2. Geryon quinquedens. Daily survivorship for larvae raised on either the rotifer Brachionus plicatilis or the nauplius of the brine shrimp Artemia salina 
Table 1. Menippe mercenaria. Percent survival for each zoeal stage for larvae fed either brine shrimp nauplius or rotifer diet

\begin{tabular}{|ccc|}
\hline \multirow{2}{*}{ Zoeal stage } & \multicolumn{2}{c|}{ Diet } \\
& Brine shrimp & Rotifers \\
\hline I & 68.2 & 73 \\
II & 61.8 & 39 \\
III & 56.4 & 6 \\
IV & 41.8 & 0 \\
V & 31.8 & - \\
\hline
\end{tabular}

Table 2. Menippe mercenaria. Mean day (and range) of each molt for larvae fed either brine shrimp nauplius or rotifer diet. Results of a Student's t-test comparing the means for each molt are shown in the right column

\begin{tabular}{|rrrc|}
\hline Molt & \multicolumn{2}{c}{ Diet } & $\begin{array}{c}\text { t-test } \\
\text { Probability }\end{array}$ \\
\hline Brine shrimp & Rotifers & \\
II & $8.7(8-10)$ & $8.3(7-9)$ & $<0.001$ \\
III & $14.4(12-17)$ & $14.3(12-17)$ & $>0.05$ \\
IV & $19.1(16-25)$ & $22.0(20-24)$ & $<0.001$ \\
V & $25.7(22-33)$ & - & - \\
& $33.8(30-38)$ & - & - \\
\hline
\end{tabular}

\section{Geryon quinquedens}

The graph in Figure 2 shows daily survivorship for larvae raised on rotifers and brine shrimp nauplii. Survival to the megalopa occurred on both diets. Table 3 lists cumulative survival on a stage by stage basis. For each stage, the data were transformed (arc sine) and compared using a Student's t-test. There are no statistically different survival rates through zoeal development.

Figure 3 shows the mean (and range) for each molt for larvae raised on the two diets. For each molt, mean days were compared using a Student's t-test. Molt I shows no significant difference between means $(p>$ 0.05), but Molts II-IV each show significance ( $\mathrm{p}<$ $0.001)$.

In order to evaluate the effects of diet during zoeal

Table 3. Geryon quinquedens. Percent survival for each zoeal stage for larvae fed either brine shrimp nauplii or rotifer diet. Results of a Student's t-test comparing the mean per cent survival for each stage are shown in the right column

\begin{tabular}{|rccc|}
\hline $\begin{array}{c}\text { Zoeal } \\
\text { stage }\end{array}$ & Brine shrimp & Rotifer & $\begin{array}{c}\text { t-test } \\
\text { Probability }\end{array}$ \\
\hline I & 55.7 & 50.7 & $>0.05$ \\
II & 49.3 & 43.6 & $>0.05$ \\
III & 47.1 & 42.1 & $>0.05$ \\
IV & 34.3 & 19.3 & $>0.05$ \\
& & & \\
\hline
\end{tabular}

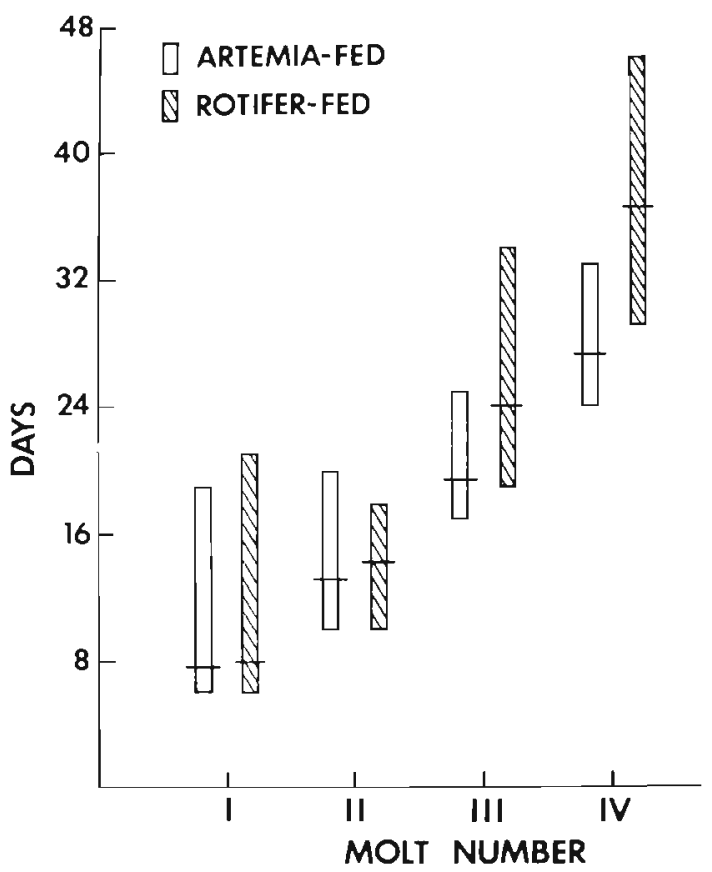

Fig. 3. Geryon quinquedens. Mean day and range for each molt for larvae raised on the two test diets

development on subsequent megalopa development, all megalopa obtained via either diet were raised to the first crab stage using brine shrimp nauplii. Mean duration of megalopa life was determined and compared statistically (Student's t-test). Mean megalopa duration for brine shrimp-fed zoea was $23.3 \mathrm{~d}$; for rotifer-fed zoeae, $22.9 \mathrm{~d}(\mathrm{p}>0.05)$.

\section{DISCUSSION}

Sulkin (1978) has suggested that nutritional vulnerability is characteristic of a primitive reproductive strategy in brachyuran crabs. This was based on results which showed that the xanthid crabs Rhithropanopeus harrisii and Neopanope texana sayi could complete zoeal development on laboratory diets which were unable to sustain the blue crab Callinectes sapidus. The results reported here for Menippe mercenaria are consistent with that hypothesis.

Long pelagic duration, large and variable numbers of instars, and production of large numbers of eggs per spawn are features considered characteristic of a primitive reproductive strategy by LeBour (1928) and others. The data in Table 4 compare these features between Menippe mercenaria and another xanthid, Rhithropanopeus harrisii. Using these features as criteria, the reproductive strategy of $M$. mercenaria would be classified as more primitive than that of $R$. harrisii. Using ability to develop to metamorphosis on 
Table 4. Comparison of selected characteristics of reproduction between two species of the Family Xanthidae. Data for length of pelagic duration based on laboratory studies at $25{ }^{\circ} \mathrm{C}:{ }^{1}$ Porter, $1960 ;{ }^{2}$ Present Study; ${ }^{3}$ Binford, $1912 ;{ }^{4} \mathrm{Connolly}, 1925 ;{ }^{5} \mathrm{Costlow}$ et al., 1966; ${ }^{6}$ Turboyski, $1973 ;{ }^{7}$ Sulkin and Norman, 1976

\begin{tabular}{|lcccc|}
\hline Species & $\begin{array}{c}\text { Pelagic } \\
\text { duration } \\
\text { (days) }\end{array}$ & $\begin{array}{c}\text { Number } \\
\text { of } \\
\text { instars }\end{array}$ & $\begin{array}{c}\text { Egg production } \\
\text { per spawn }\end{array}$ & $\begin{array}{c}\text { Development } \\
\text { on rotifer } \\
\text { diet }\end{array}$ \\
\hline $\begin{array}{l}\text { Menippe mercenaria } \\
\text { Rhithropanopeus harrisii }\end{array}$ & $27-34^{1,2}$ & $5-6^{1}$ & $500,000-1,000,000^{3}$ & No $^{2}$ \\
$10-15^{4,5}$ & $4^{5}$ & $16,000^{6}$ & Yes $^{7}$ \\
\hline
\end{tabular}

the rotifer diet as the criterion, $M$. mercenaria is also nutritionally more vulnerable.

It is interesting to note that as with the blue crab Callinectes sapidus (Sulkin, 1975), the hatching stage shows higher survival and faster development on the rotifer diet than on diets which can support completed development.

Although there is clear evidence that the rotifer diet causes a delay in the larval development of Geryon quinquedens, there is no difference in the survivorship to the megalopa between larvae raised on the two test diets. The nutritional flexibility of $G$. quinquedens is remarkable when considered in the context of the results for Menippe mercenaria, other xanthids (Sulkin and Norman, 1976) Callinectes sapidus (Sulkin, 1975, 1978), and Ovalipes ocellatus (Sulkin, unpublished). Although final interpretation must await identification of the nature of dietary requirements in these species, it seems reasonable to suggest that biochemical adaptations have occurred in G. quinquedens which provide the species with considerable flexibility in choice of prey species.

Our results suggest a possible ecological significance to nutritional vulnerability (or its reciprocal, flexibility). The species tested prior to this study hatch their larvae in relatively shallow water of the estuarine or coastal marine environment, as does Menippe mercenaria. Larvae of these species can readily reach productive, near-shore surface waters which are likely to contain the kinds of prey required to satisfy nutritional needs. Larvae of Geryon quinquedens, however, hatch at depths exceeding $200 \mathrm{~m}$, at water temperatures less than $12{ }^{\circ} \mathrm{C}$. Even assuming that they eventually reach surface waters, the vertical excursion will be time consuming and energy demanding. The diversity of living prey available to them will be comparatively low during the early part of development. Our results suggest that adaptations have occurred which have increased the nutritional flexibility of larvae of this deep water species and thus have reduced their dependence on locating and capturing specific prey needed to satisfy qualitative nutritional requirements.

It is difficult to assign evolutionary significance to these adaptations particularly considering the confu- sion and controversy over the systematic position of the genus (Perkins, 1973). However, it is tempting to speculate that evolution of nutritional flexibility during larval development was a necessary condition for penetration of the deep sea environment by crabs which retained planktotrophic larvae.

Acknowledgements. The authors wish to thank Sue Hill, Robert Miller, and Laurie van Heukelem for technical assistance. This project was supported in part by the National Science Foundation through its Undergraduate Research Participation program (SMI-76-83577) and the Maryland Sea Grant program (Project R/F-15).

\section{LITERATURE CITED}

Anger, K., Nair, K. K. C. (1979). Laboratory experiments on the larval development of Hyas araneus (Decapoda, Majidae). Helgoländer wiss. Meeresunters. 32: 36-54

Bigford, T. E. (1978). Effect of several diets on survival, development time, and growth of laboratory-reared spider crab, Libinia emarginata, larvae. Fish. Bull. U. S. 76 : $59-64$

Binford, R. (1912). The germ cells and the process of fertilization in the crab, Menippe mercenaria. Ph D. thesis, The Johns Hopkins University

Connolly, C. J. (1925). The larval stages and megalopa of Rhithropanopeus harrisii (Gould). Contr. Can. Biol. N. S. 2: 329-337

Costlow, J. D., Jr., Bookhout, C. G., Monroe, R. J. (1966) Studies on the larval development of the crab, Rhithropanopeus harrisii (Gould). I. The effect of salinity and temperature on larval development. Physiol. Zoöl. 39: $81-100$

Haefner, P. A, Jr. (1978). Seasonal aspects of the biology, distribution, and relative abundance of the deep sea red crab Geryon quinquedens Smith, in the vicinity of the Norfolk Canyon, Western North Atlantic. Proc. natn. Shellfish. Ass. 68: 49-62

LeBour, M. V. (1928). The larval stages of the Plymouth Brachyura. Proc. Zool. Soc. Lond. 1928: 473-560

Perkins, H. C. (1973). The larval stages of the deep sea red crab, Geryon quinquedens Smith, reared under laboratory conditions (Decapoda: Brachyrhyncha). Fish. Bull. U. S. 71: $69-82$

Porter, W. J. (1960). Zoeal stages of the stone crab, Menippe mercenaria Say. Chesapeake Sci. 1: 168-177 
Sulkin, S. D. (1975). The significance of diet in the growth and development of larvae of the blue crab, Callinectes sapidus Rathbun, under laboratory conditions. J. exp. mar. Biol. Ecol. 20: 119-135

Sulkin, S. D. (1978). Nutritional requirements during larval development of the portunid crab, Callinectes sapidus Rathbun. J. exp. mar. Biol. Ecol. 34: 29-41

Sulkin, S. D., Epifanio, C. E. (1975). Comparison of rotifers and other diets for rearing early larvae of the blue crab, Callinectes sapidus Rathbun. Estuar. \& Coast. Mar. Sci. 3: 109-113
Sulkin, S. D., Norman, K. (1976). A comparison of two diets in the laboratory culture of the zoeal stages of the brachyuran crabs Rhithropanopeus harrisii and Neopanope sp. Helgoländer wiss. Meeresunters. 28: 183-190

Turboyski, K. (1973). Biology and ecology of the crab, Rhithropanopeus harrisii tridentatus. Mar. Biol. 23: 303-313

Wigley, R. L., Theroux, R. B., Murray, H. E. (1975). Deep sea red crab, Geryon quinquedens, survey off northeastern United States. Mar. Fish. Rev. 37: 1-21

This paper was submitted to the editor; it was accepted for printing on November 21, 1979. 